\title{
Severe vivax malaria trends in the last two years: a study from a tertiary care centre, Delhi, India
}

\author{
Monika Matlani', Loick P. Kojom ${ }^{2}$, Neelangi Mishra' ${ }^{1}$, Vinita Dogra ${ }^{1}$ and Vineeta Singh ${ }^{2 *}$
}

\begin{abstract}
Background: Plasmodium vivax, once considered benign species, is recently being recognised to be causing severe malaria like Plasmodium falciparum. In the present study, the authors report the trends in malaria severity in P. vivax among patients from a Delhi government hospital. The aim of the study was to understand the disease severity and the burden of severe vivax malaria.

Methods: A hospital based study was carried out from June 2017 to December 2018 at a tertiary care centre from Delhi, India. Patients were tested for malaria using peripheral blood smear (PBS) and/or rapid malaria antigen test (RMAT). The severe and non-severe vivax malaria categorization was done as per the WHO guidelines. Sociodemographic, clinic and paraclinical data were collected from patients and their medical records.

Results: Of the 205 patients, 177 (86.3\%) had P. vivax infection, 22 (10.7\%) had P. falciparum infection and six (2.9\%) had mixed infection with both the species. Out of 177 P. vivax cases included in this study one or more manifestations of severe malaria was found in 58 cases (32.7\%). Severe anaemia (56.9\%), jaundice (15\%) and significant bleeding $(15 \%)$ were the most common complications reported in most of patients, along with thrombocytopenia.

Conclusions: In this study, it is evident that vivax malaria is emerging as the new severe disease in malaria patients, a significant shift in the paradigm of $P$. vivax pathogenesis. The spectrum of complications and alterations in the laboratory parameters in P. vivax clinical cases also indicate the recent shift in the disease severity.
\end{abstract}

Keywords: Plasmodium vivax, Vivax malaria, Clinical trends, Disease severity, India

\section{Background}

Malaria still remainsa global public health problem. According to the World Malaria Report 2019, India accounts for $4 \%$ of all estimated cases of malaria worldwide [1]. India is an endemic region with more than half of the population [698 million] at risk for malaria infections annually where Plasmodium vivax is solely responsible for about $50 \%$ of the reported malaria cases [2]. A broad spectrum of clinical features may be manifested in

${ }^{*}$ Correspondence: vineetas_2000@yahoo.com

${ }^{2}$ Cell Biology Laboratory and Malaria Parasite Bank, ICMR-National Institute of Malaria Research, New Delhi, India

Full list of author information is available at the end of the article humans following the bite of female Anopheles mosquitoes with inoculation of the Plasmodium species into the blood circulation, leading to asymptomatic parasitaemia, uncomplicated and severe malaria with associated deaths [3]. The outcome of the malaria disease is influenced by various factors like infecting Plasmodium species, host immunity and efficacy of treatment [4]. In endemic areas, some of the important risk factors responsible for the severity of disease including the age of the patient, early and frequent relapses with limited access to early diagnosis and treatment, along with prevalence of comorbidities such as bacterial co-infections [5-7].

Historically, $P$. vivax is known to cause benign tertian malaria, but in recent years a change in this trend has

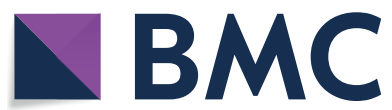

(c) The Author(s) 2020. This article is licensed under a Creative Commons Attribution 4.0 International License, which permits use, sharing, adaptation, distribution and reproduction in any medium or format, as long as you give appropriate credit to the original author(s) and the source, provide a link to the Creative Commons licence, and indicate if changes were made. The images or other third party material in this article are included in the article's Creative Commons licence, unless indicated otherwise in a credit line to the material. If material is not included in the article's Creative Commons licence and your intended use is not permitted by statutory regulation or exceeds the permitted use, you will need to obtain permission directly from the copyright holder. To view a copy of this licence, visit http://creativeco mmons.org/licenses/by/4.0/. The Creative Commons Public Domain Dedication waiver (http://creativecommons.org/publicdomain/ zero/1.0/) applies to the data made available in this article, unless otherwise stated in a credit line to the data. 
been observed with life-threatening symptoms similar to those of $P$. falciparum infections [3]. The most common clinical complications increasingly reported due to severe $P$. vivax malaria are severe anaemia, acute respiratory distress syndrome (ARDS), splenic rupture and acute kidney injury [8]. Several recent reports indicate this significant shift in the paradigm of $P$. vivax $[9,10]$.

Despite being globally recognised recently, to cause severe disease and mortality, there is still meagreness in estimating the exact burden of severe disease due to $P$. vivax, which poses the need for further studies especially in vivax endemic regions [11, 12]. Here, a prospective observational study was performed to determine the proportion of disease severity, the spectrum of complications and alterations in laboratory parameters in $P$. vivax malaria infections among patients admitted at a tertiary care centre from New Delhi, India.

\section{Methods}

\section{Study area}

This study was conducted in a tertiary care centre situated in New Delhi. The region is hypoendemic for malaria with an annual parasite index of less than 1 [13]. This hospital is a 2400 bedded tertiary care hospital, which caters to patients from whole of northern zone of India with daily outpatient department (OPD) visit of $8000-10,000$ patients per day. The monsoon season in Delhi is from July to September months and a surge in malaria cases is observed every year from August to October, the malaria transmission months in this region. According to the data from the National Vector Borne Disease Control Program, P. vivax is the predominant species in Delhi State, with prevalence rate $>90 \%$ each year [14]. This study was carried out over one and a half years, from June 2017 till December 2018, to include disease transmission period of both the years 2017 and 2018 .

\section{Patients and ethical statement}

This study included the patients enrolled in the OPD and tested positive for malaria. Ethical clearance was taken by the Ethics Committee before the beginning of the study [IEC/SJH/VMMC/Project/ 2017/983]. A written informed consent was obtained from each study participant or guardian of the wards, and confidentiality of the participant's test results was ensured throughout the research. Each study participant was given a unique numerical code in order to streamline the data collection. The inclusion and exclusion criteria of the study were as following:

\section{Inclusion criteria}

a) Patients presenting with undifferentiated fever for minimum five days with clinical suspicion of malaria.

b) Patients whose blood sample was positive for malaria by peripheral blood smear (PBS) and Rapid malarial antigen test (RMAT), with or without clinical suspicion of malaria.

c) Availability of informed written consent and completed performa.

\section{Exclusion criteria}

a) Non- availability of informed written consent.

b) Patients positive for any other illness other than malaria.

\section{Sample size}

The minimal sample size required for the study was computed using the following formula of Lorentz: $\mathrm{N}=\mathrm{p}(1-\mathrm{p})$ $\mathrm{z}^{2} / \mathrm{d}^{2}$ where $\mathrm{N}$ is the minimal sample size; $\mathrm{p}$ is the prevalence of severe vivax malaria (62.9\%) reported previously [11]; $d$ the accepted margin of error $(d=0.05)$ and $z$ the statistic for the desired confidence level $(z=1.96$ for confidence at $95 \%$ ). Thus, a total sample size of 302 individuals was minimally required for this study.

\section{Diagnosis}

A detailed clinical history of the consenting patients was taken and a thorough physical examination was performed. Laboratory investigations were performed to establish the diagnosis of malaria and assess the severity of the disease in these patients.

PBS and RMAT were the diagnostic methods used to detect malaria species in blood samples of patients. The RMAT used in the study is designed to detect two malarial antigens: (1) Histidine rich protein-2 (HRP-2), a protein specifically produced by P. falciparum, and (2) Pan malarial lactate dehydrogenase ( $\mathrm{p}-\mathrm{LDH})$, produced by all malarial species. Giemsa stained thick and thin PBS were examined for the identification of species and counting of malarial parasites, respectively. PBS and RMAT were performed by skilled operators to ascertain the quality of sample. RMAT results were classified as valid (positive or negative) and invalid [15]. The parasite count was calculated from the number of parasitized cells/200 leukocytes in a Giemsa stained thick smears [16]. On the basis of the species identification, the patients were categorized into three groups- 1) P. vivax infections, 2) P. falciparum infections and 3) mixed infections of $P$. falciparum and $P$. vivax. The classification as severe and non-severe 
vivax malaria was done following WHO guidelines [17]. The patients with uncomplicated malaria were treated following the standard guidelines of national program for malaria treatment, i.e., artesunate-sulfadoxinepyrimethamine (AS $+\mathrm{SP})$ for 3 days plus single dose primaquine (PQ) on the second day in case of falciparum malaria; chloroquine for 3 days plus PQ for 14 days for vivax malaria; and, $\mathrm{AS}+\mathrm{SP}$ for 3 days plus $\mathrm{PQ}$ for 14 days in case of mixed infection with $P$. vivax and $P$. falciparum [18]. Patients with severe malaria were treated with intravenous artesunate [18].

\section{Demographical characteristics}

Data regarding age, gender and pregnancy status were collected using an ad hoc investigation form conceived for the need of the study.

\section{Laboratory investigations}

The venous blood samples were collected in ethylenediaminetetraacetic acid (EDTA) anticoagulant vacutainer tubes for serological, haematological and biochemical investigations. Complete blood counts, coagulation profile tests, blood glucose, blood urea, serum creatinine, serum electrolytes, serum bilirubin, serum aspartate aminotransferase (AST), serum alanine aminotransferase (ALT) were measured for patients positive for P. vivax. Appropriate serological tests were also performed to exclude enteric fever, dengue, chikungunya, scrub typhus and leptospirosis.

\section{Statistical analysis}

Data were keyed into an Excel spreadsheet (Microsoft office 2016, USA) and analysed using the statistical package for social sciences v16 for Windows (SPSS, Chicago, IL, USA). Qualitative and quantitative variables were expressed as frequency (percentages) and mean \pm standard deviation (SD), respectively. Confidence interval at 95\% (95\% CI) of percentages was computed. Parasitemia values were $\log _{10}$-transformed before statistical analysis. Pearson's chi square and Fisher's exact tests were used to compare percentages, while unpaired sample $t$ test was used to compare mean values. Significance was set at p-value $<0.05$.

\section{Results}

The onset of malaria case reporting is observed mostly after the raining season annually between the months of August-October (the malaria transmission period) in Delhi and other neighbouring regions. Maximum number of cases were recorded in October 2018 (65 cases) followed by September 2018 (51 cases). A total of 205 confirmed cases of malaria were enrolled in the study, after inclusion criteria were satisfied. Of the 205 patients,
177 (86.3\%) were positive for $P$. vivax infection, 22 (10.7\%) had P. falciparum infection and six (2.9\%) showed mixed infections as diagnosed by PBS and RMAT (Fig. 1). There was a predominance of trophozoites and gametocytes in the peripheral blood smears examined, and parasite density ranged from $200-17,800$ parasites/ $\mu$ l (Fig. 2). The $P$. vivax group comprised 100 children ( $<14$ years) and 77 adults. The age of the participants ranged from 2 to 58 years with a median age of 13 years. The number of male patients was higher in both age groups i.e., below 14 years and above 14 years (Table 1 ).

In the $177 P$. vivax cases, fever was present in all the patients. Of these, 119 patients $(67.2 \%)$ had uncomplicated malaria while the remaining 58 (32.7\%) were suffering from complicated malaria. In addition, 41 of these 58 patients, had only a single complication, while 17 cases presented $>1$ or multiple complications (Fig. 1, Table 2). Thus, the prevalence of severe vivax malaria was found to be $32.7 \%$ (95\% CI $26.3-40.0 \%$ ).

A total of 13 vivax-related severe complications were found in the studied patients (Fig. 3). Severe anaemia was the most frequent complication found in the study $(\mathrm{n}=33,56.9 \%)$ followed by significant bleeding $(\mathrm{n}=9$, $15 \%)$, jaundice $(\mathrm{n}=9,15 \%)$ and multiple convulsions $(\mathrm{n}=8,13.8 \%)$. Central nervous system (CNS) manifestations in the form of generalised tonic-clonic seizures and altered sensorium were observed in about $4 \%$ of the patients which had only 5 children in this group.

All the patients who presented with either seizures or altered sensorium were suspected to be having cerebral malaria attributed to $P$. vivax infection. The analysis of cerebrospinal fluid, computed tomography scan of head, fundoscopy and serum electrolyte studies were also performed to exclude other (bacterial, fungal or viral) CNS infections. Abnormal bleeding was observed in 11 patients $(6.2 \%)$ in whom epistaxis, hematemesis, haematuria and melena were also observed. On physical examination 50 patients (30.5\%) had hepato-splenomegaly, 4 individuals (23.2\%) showed pallor, while 15 (47\%) were icteric. Apart from these observations, the other clinical findings were oedema, rashes and hypovolemic shock. Clinical details of the patients are shown in Table 2.

The comparative analysis of the prevalence of clinical features in patients diagnosed with severe and uncomplicated malaria revealed statistically significant variations between both groups $(P<0.05)$. Prevalence of these features were significantly higher in patients with severe complications in comparison to their counterparts diagnosed with uncomplicated malaria (Table 2).

In patients with severe manifestations hepatosplenomegaly was observed to be significantly higher $(84.5 \%$, $\mathrm{P}<0.0001)$ in comparison to patients presenting uncomplicated malaria (4.2\%). The same pattern was observed 


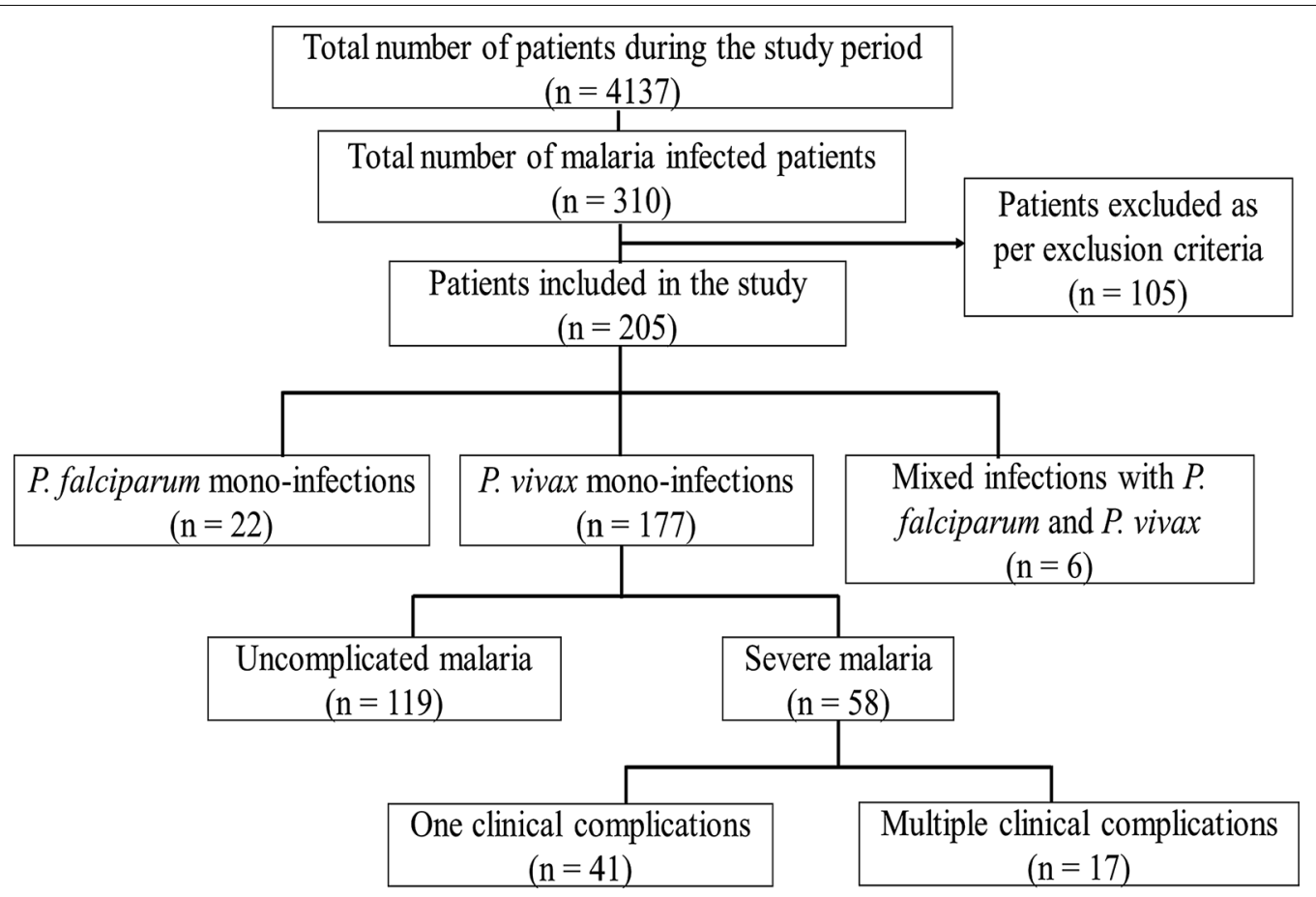

Fig. 1 Flowchart of the identification of severe vivax malaria in the study

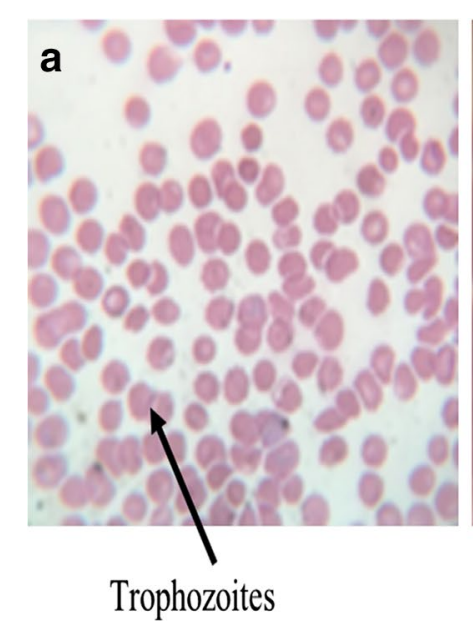

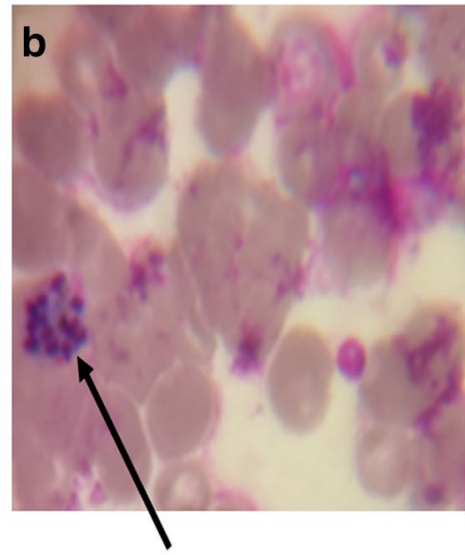

Schizonts

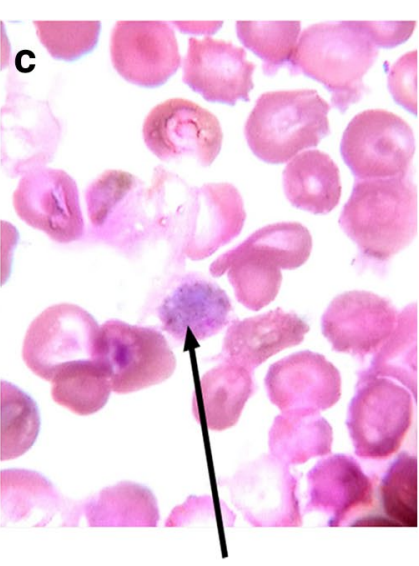

Gametocytes

Fig. 2 a Photographs of trophozoites, b schizonts and c gametocytes of P. vivax blood smears from the study

Table 1 Demographic details of the positive Plasmodium vivax patients

\begin{tabular}{lclr}
\hline Age groups & Male & Females & Total \\
\hline$<14$ yrs & 58 & 42 & 100 \\
$>14$ yrs & 47 & 30 & 77 \\
Total & 105 & 72 & 177 \\
\hline
\end{tabular}

for altered sensorium $(12.1 \%$ vs $0.0 \%, \mathrm{P}<0.0001)$, jaundice $(25.9 \%$ vs $0.0 \%, \mathrm{P}<0.0001)$, hypovolemic shock $(6.8 \%$ vs $0.0 \%, \mathrm{P}<0.0001)$, oedema $(13.8 \%$ vs $0.0 \%, \mathrm{P}<0.0001)$ (Table 2).

Details of the laboratory parameters revealed low haemoglobin level in the analysed samples (Table 3). Different degree of anaemia severity was observed in 130 
Table 2 Details of clinical features observed in severe and uncomplicated cases of vivax malaria

\begin{tabular}{|c|c|c|c|c|c|}
\hline Clinical features & $\begin{array}{l}\text { Severe malaria } \\
(n=58)(\%)\end{array}$ & $\begin{array}{l}\text { Uncomplicated } \\
\text { malaria }(n=119)(\%)\end{array}$ & $\begin{array}{l}\text { Total number } \\
\text { of patients }(n=177) \\
\text { (\%) }\end{array}$ & Chi-square (df) & $P$ \\
\hline Hepatosplenomegaly & $49(84.5)$ & $5(4.2)$ & $54(30.5)$ & $109.9(1)$ & $<0.0001^{*}$ \\
\hline Headache & $51(87.9)$ & $9(7.6)$ & $30(17.0)$ & $108.8(1)$ & $<0.0001^{*}$ \\
\hline Pallor & $36(62.1)$ & $5(4.2)$ & $41(23.2)$ & $70.2(1)$ & $<0.0001^{*}$ \\
\hline Seizures (> 2 episodes in 24 h) & $8(13.8)$ & $0(0.0)$ & $8(4.5)$ & $14.1(1)$ & $0.0002^{*}$ \\
\hline Altered sensorium & $7(12.1)$ & $0(0.0)$ & $7(3.9)$ & $11.7(1)$ & $0.0006^{*}$ \\
\hline Vomiting & $12(20.7)$ & $4(3.4)$ & $16(9.03)$ & $12.2(1)$ & $0.0005^{*}$ \\
\hline Jaundice (Bilirubin > 2 mg\%) & $15(25.9)$ & $0(0.0)$ & $15(8.47)$ & $30.3(1)$ & $<0.0001^{*}$ \\
\hline Epistaxis & $8(13.8)$ & $0(0.0)$ & $8(4.60)$ & $14.1(1)$ & $0.0002^{*}$ \\
\hline Haematuria & $3(5.2)$ & $0(0.0)$ & $3(1.70)$ & $3.5(1)$ & 0.0599 \\
\hline Hematemesis & $2(3.4)$ & $0(0.0)$ & $2(1.10)$ & $1.64(1)$ & 0.2003 \\
\hline Melena & $2(3.4)$ & $0(0.0)$ & $2(1.10)$ & $1.64(1)$ & 0.2003 \\
\hline Hypovolemic shock $(\mathrm{SBP}<80 \mathrm{mmHg})$ & $4(6.8)$ & $0(0.0)$ & $4(2.3)$ & $5.5(1)$ & $0.0184^{*}$ \\
\hline Breathlessness & $14(24.1)$ & $1(0.8)$ & $15(8.47)$ & $24.3(1)$ & $<0.0001^{*}$ \\
\hline Pulmonary oedema & $8(13.8)$ & $0(0.0)$ & $8(4.60)$ & $14.1(1)$ & $0.0002^{*}$ \\
\hline Rash & $4(6.8)$ & $0(0.0)$ & $4(2.26)$ & $5.5(1)$ & $0.0184^{*}$ \\
\hline Decreased urine output & $7(12.1)$ & $0(0.0)$ & $7(3.95)$ & $11.7(1)$ & $0.0006^{*}$ \\
\hline
\end{tabular}

The occurrence of clinical manifestations as listed in the table were found to be statistically significant as values for $\mathrm{P}$ were mostly $<0.05$ between the two groups Data are presented as frequency (percentage) and mean \pm standard deviation SBP: Systolic blood pressure, df: Degree of freedom Pearson's chi-square test was used to compare percentages

* : Statistically significant at $\mathrm{P}<0.05$

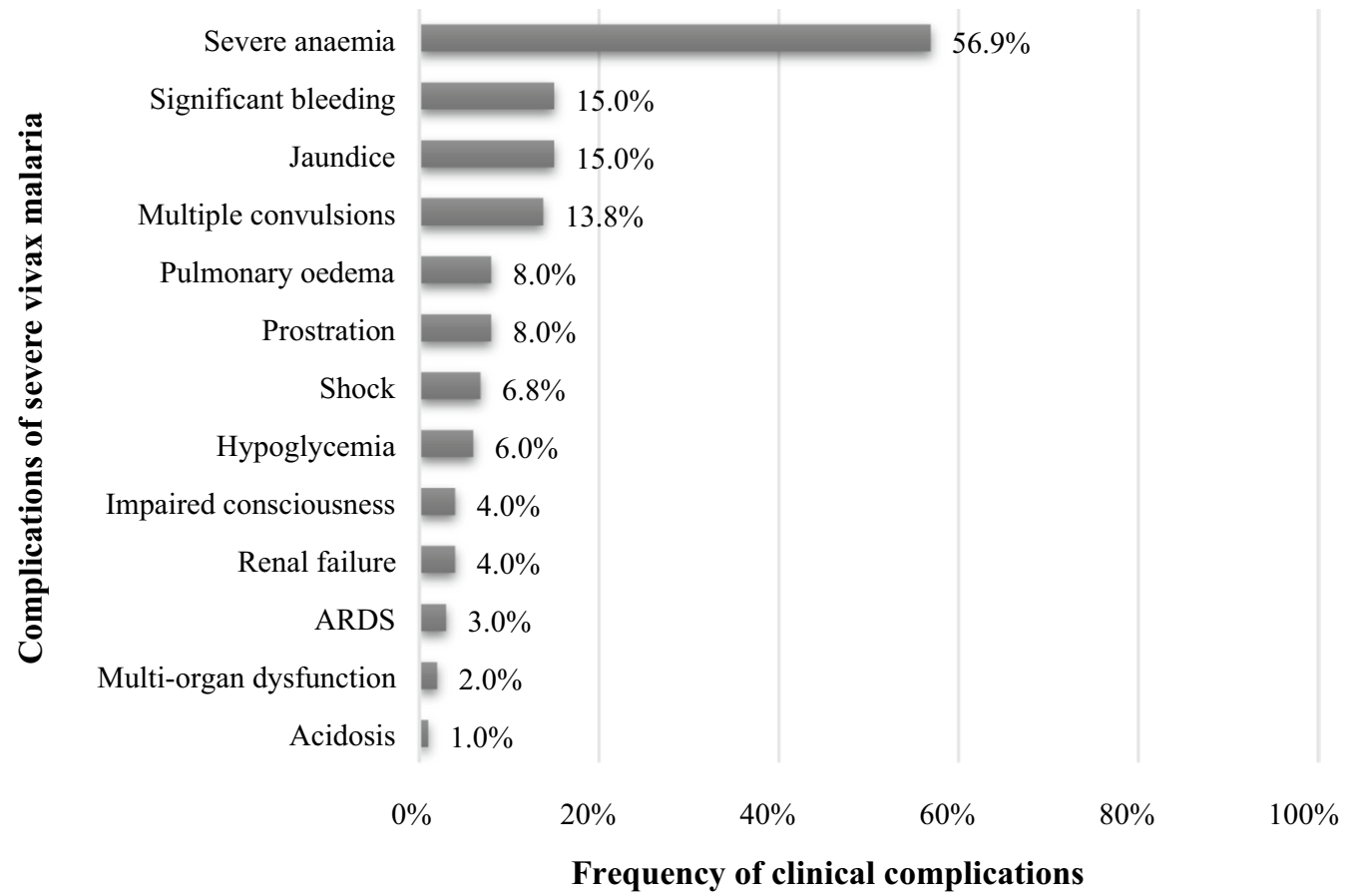

Fig. 3 Frequency of different complications observed in patients diagnosed with severe vivax malaria (SVM) during the study period 
Table 3 Laboratory parameters of severe verses uncomplicated cases of malaria

\begin{tabular}{|c|c|c|c|c|c|}
\hline Laboratory parameters & $\begin{array}{l}\text { Severe malaria } \\
n=58(\%)\end{array}$ & $\begin{array}{l}\text { Uncomplicated } \\
\text { malaria } n=119(\%)\end{array}$ & $\begin{array}{l}\text { Total number } \\
\text { of patients } n=177(\%)\end{array}$ & Chi-square (df) & $P$ \\
\hline 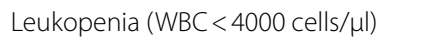 & $15(25.9)$ & $10(8.4)$ & $25(14.1)$ & $8.4(1)$ & $0.0037^{*}$ \\
\hline Leukocytosis (WBC > 10,000 cells/ $\mu$ l) & $6(10.3)$ & $0(0.0)$ & $6(3.4)$ & $9.8(1)$ & $0.0018^{*}$ \\
\hline Severe anaemia & $33(56.9)$ & $0(0.0)$ & $33(18.7)$ & $79.5(1)$ & $<0.0001^{*}$ \\
\hline Moderate anaemia & $15(25.9)$ & $9(7.6)$ & $24(13.5)$ & $9.6(1)$ & $0.0019^{*}$ \\
\hline Mild anaemia & $38(65.5)$ & 39 (32.8) & $67(37.9)$ & $15.7(1)$ & $<0.0001^{*}$ \\
\hline Thrombocytopenia ( $<150,000$ cells/ $\mu$ l) & $52(89.7)$ & $64(53.8)$ & $116(65.5)$ & $20.7(1)$ & $<0.0001^{*}$ \\
\hline Deranged AST & $24(41.4)$ & $13(10.9)$ & $37(20.9)$ & $20.1(1)$ & $<0.0001^{*}$ \\
\hline Deranged ALT & $26(44.8)$ & $17(14.3)$ & $43(24.3)$ & $18.2(1)$ & $<0.0001^{*}$ \\
\hline Serum bilirubin $>2.5 \mathrm{mg} / \mathrm{dL}$ & $15(28.9)$ & $2(1.7)$ & $17(9.6)$ & $23.6(1)$ & $<0.0001^{*}$ \\
\hline Mean $\mathrm{Hb} \pm \mathrm{SD}$ & $11.5 \pm 1.7$ & $13.4 \pm 1.9$ & - & & $0.0024^{*}$ \\
\hline Mean RBC count (cells/ul) & $2.51 \times 10^{6}$ & $3.41 \times 10^{6}$ & - & & $0.0478^{*}$ \\
\hline
\end{tabular}

Data are presented as frequency (percentage) and mean \pm standard deviation (SD)

ALT, Alanine aminotransferase, AST, Aspartate aminotransferase, RBC, Red blood cells, df, Degree of freedom, WBC: White blood cells

Pearson's chi square and unpaired Student $t$ tests were used to compare percentages and mean values respectively

* : Statistically significant at $\mathrm{P}<0.05$

(73.4\%) patients, amongst whom the anaemia was graded as mild ( $\mathrm{Hb} 9-11 \mathrm{mg} \%$ ), moderate ( $\mathrm{Hb} 7-9 \mathrm{mg} \%$ ) and severe $(\mathrm{Hb}<7 \mathrm{mg} \%)$ (Table 3). The mean haemoglobin (Hb level) was $4.2 \mathrm{mg} \%$ (Table 3). Thrombocytopenia was seen in 116 (65.5\%) patients; however none of the patients had any life threatening haemorrhagic episodes. The lowest platelet count recorded was $7000 / \mu \mathrm{l}$ in 1 patient with concurrent dengue infection.

Pancytopenia was seen in 15 cases $(8.5 \%)$ and packed red cells infusion was given in 2 patients. Deranged liver enzymes and high concentration of serum bilirubin was observed in $24.3 \%$ of $P$. vivax patients. Four of the patients who had developed hypovolemic shock with oliguria, loss of consciousness and systolic blood pressure $<80 \mathrm{mmHg}$ were treated with ionotropic agents and fluid replacement also recovered. Two pregnant patients in their third trimester presenting acute febrile illness with anaemia (haemoglobin $<10 \mathrm{gm} \%$ ) were also included in the study group. Later, during the study intrauterine deaths were reported in these pregnant patients as neither foetal movements were felt, nor foetal heart sounds were heard and with no other co-morbid conditions. There were 3 cases with dengue co-infections with 1 patient had enteric fever co-infection. No mortality was observed during the course of this study.

All laboratory parameter levels significantly varied according to the severity of vivax malaria (Table 3). Levels of these parameters were significantly higher in severe malaria patients than in uncomplicated malaria patients, with the exception of mean values of $\mathrm{Hb}$ and red blood cells $(\mathrm{RBC})$ that were significantly decreased in patients suffering from severe vivax malaria. For instance, the prevalence of leukopenia, severe anaemia and thrombocytopenia were respectively $25.9 \%, 56.9 \%$ and $89.7 \%$ in severe patients while they were $8.4 \%, 0 \%$ and $56.8 \%$ in uncomplicated malaria patients (Table 3 ).

The evolution of different haematological features according to vivax parasitemia levels is depicted in Table 4. Statistically significant associations were found for three features viz severe anaemia, mean corpuscular volume (MCV) and mean corpuscular haemoglobin $(\mathrm{MCH})$. The prevalence of severe anaemia gradually increased as a function of parasitemia, from $22.2 \%$ in patient group with parasitemia $<100$ parasites $/ \mu$ lo $45.5 \%$ in patient group with parasitemia $>10,001$ parasites/ $\mu \mathrm{l}(\mathrm{P}=0.0139)$. Similarly, the prevalence of patients with $\mathrm{MCV}$ below normal ranged from $60.5 \%$ in patient group with parasitemia $<100$ parasites/ $\mu$ l to $100 \%$ in patient group with parasitemia $>10,001$ parasites $/ \mu \mathrm{l}$ $\mathrm{P}=0.0351$ ). In contrast, no statistically significant difference was found in total leucocyte count (TLC) between both groups.

\section{Discussion}

The clinical course of malaria depends on several host and parasite-related factors and it manifests with a multitude of signs and symptoms. The disease spectrum progresses from stage of asymptomatic parasitemia to uncomplicated malaria, severe malaria and leading to death in some cases. Severe or complicated malaria is more often associated with $P$. falciparum infection, in which increased sequestration of RBC in the microvasculature and massive haemolysis lead to complications like cerebral malaria (CM), renal dysfunction, hepatic 
Table 4 Parasitemia levels of Plasmodium vivax and changes in haematological parameters in the studied patients

\begin{tabular}{|c|c|c|c|c|c|c|}
\hline \multirow[b]{2}{*}{ Variables } & \multirow[b]{2}{*}{ Categories } & \multicolumn{3}{|c|}{$\begin{array}{l}\text { Parasitemia range (P. vivax mono-infection) (number } \\
\text { of parasites/ } \mu \text { l of blood) }\end{array}$} & \multirow[b]{2}{*}{ Total $n=177$} & \multirow[b]{2}{*}{$P$} \\
\hline & & $<100[n=81(\%)]$ & $\begin{array}{l}101-10000 \\
{[n=85(\%)]}\end{array}$ & $>10001[n=11(\%)]$ & & \\
\hline \multirow[t]{4}{*}{ Grading of anaemia } & Non-anaemic & $24(29.6)$ & $29(34.1)$ & $0(0)$ & 53 & 0.0669 \\
\hline & Mild anaemia & $31(38.3)$ & $34(40.0)$ & $2(18.2)$ & 67 & 0.3716 \\
\hline & Moderate anaemia & $8(9.9)$ & $12(14.1)$ & $4(36.4)$ & 24 & 0.0539 \\
\hline & Severe anaemia & $18(22.2)$ & $10(11.8)$ & $5(45.5)$ & 33 & $0.0139^{*}$ \\
\hline Thrombocytopenia & Presence & $52(64.2)$ & $57(67.1)$ & $7(63.6)$ & 116 & 0.9185 \\
\hline \multirow[t]{3}{*}{ Changes in TLC } & Leukopenia & $10(12.3)$ & $15(17.6)$ & $0(0)$ & 25 & 0.2357 \\
\hline & Normal TLC & $69(85.2)$ & $66(77.6)$ & $11(100)$ & 146 & 0.1275 \\
\hline & Leukocytosis & $2(2.5)$ & $4(4.7)$ & $0(0)$ & 6 & 0.5916 \\
\hline \multirow[t]{3}{*}{ Changes in MCV } & Below normal & $49(60.5)$ & $56(65.9)$ & $11(100)$ & 116 & $0.0351^{*}$ \\
\hline & Normal & $7(8.6)$ & $6(7.0)$ & $0(0)$ & 13 & 0.5827 \\
\hline & Above normal & 25 (30.9) & $23(27.1)$ & $0(0)$ & 48 & 0.0928 \\
\hline \multirow[t]{3}{*}{ Changes in $\mathrm{MCH}$} & Below normal & $28(34.6)$ & $25(29.4)$ & $0(0)$ & 53 & 0.0627 \\
\hline & Normal & $46(56.8)$ & $55(64.7)$ & $8(72.7)$ & 109 & $0.0002^{*}$ \\
\hline & Above normal & $7(8.6)$ & $5(5.9)$ & $3(27.3)$ & 15 & 0.0564 \\
\hline
\end{tabular}

Data are presented as frequency (percentage) and mean \pm standard deviation

TLC, Total leucocyte count, MCV: Mean corpuscular volume, MCH: Mean corpuscular $\mathrm{Hb}$

Fisher's exact test was used to compare percentages

* Significance was at P-value $<0.05$

dysfunction and ARDS [19]. The biological basis of development of CM is well described for P. falciparum through the cytoadherence phenomenon, whereas little is known about molecular basis of CM due to $P$. vivax [20]. There are very few studies which indicate the ability of $P$. vivax to also elicit cytoadherence [21, 22]. Beyond these parasite sequestration-related complications, nonsequestration related complications, including anaemia and thrombocytopenia are also seen in falciparum malaria [23]. Recently, reported severe manifestations of $P$. vivax infections include $\mathrm{CM}$, hepatic dysfunction, acute renal injury, severe anaemia, ARDS, splenic rupture and multiple organ failure [1]. Various studies from other countries such as Ethiopia, Papua New Guinea, Brazil, Indonesia and recently India have also described this increasing trend in the ability of $P$. vivax to elicit severe complications [1].

P. vivax accounts for one third of all malaria cases detected in India, with high prevalence in the urban areas [2]. In the present study, we report 177 febrile cases $(86.3 \%, 177 / 205)$ of vivax malaria diagnosed by PBS and RMAT where children and male population were more commonly infected. The low level of anti-P. vivax immunity observed frequently in children may explain a higher burden of malaria infection in them as found in P. falciparum [24]. A total of 58 (32.7\%) severe vivax cases were found in the present study. This value is globally lower than one of the previous studies conducted in the same area and from other Indian areas (Table 5) [11, 12, 2532]. In contrast, this prevalence value is higher than one of studies conducted outside India, especially from African (Ethiopia), Asian (Indonesia, South Korea) and Latin American (Papua New Guinea) countries [33-36].

Severe anaemia was the most frequent complication observed in the present study. This finding is in line with previous studies, which showed that this complication is frequently observed in severe $P$. vivax malaria (Table 5). Severe anaemia and haemostatic complications occur due to the potential ability of $P$. vivax to lyse not only the infected RBC, but also the normal RBC as well [36, 37]. Umbers et al. [38] and Riken et al. [39] have established that vivax-associated microvascular dysfunction along with maternal anaemia may cause deleterious uteroplacental haemodynamic instability and foetal growth restriction. Severe anaemia is one of the leading cause of deaths in pregnant and children women [23]. Also in our study, intra-uterine deaths were observed in 2 of the $P$. vivax infected pregnant patients, confirming the implication of $P$. vivax in complications of malaria in pregnancy. This finding is consistent with previous studies [40-42].

In this study, the percentage of thrombocytopenic patients was $89.7 \%(52 / 58)$ in severe malaria group, and $53.8 \%(64 / 119)$ in uncomplicated malaria group as reported also from other regions in the country (Table 5). 
Table 5 Summary of severe Plasmodium vivax malaria and complications reported from different regions of India

\begin{tabular}{|c|c|c|c|c|c|}
\hline Study & Year of data collection & Region & No. of $P$. vivax malaria cases & $\begin{array}{l}\text { Prevalence } \\
\text { of severe vivax } \\
\text { malaria }\end{array}$ & Complications observed \\
\hline Kochar et al. [25] & 2009 & Rajasthan & $\begin{array}{l}1091 \text { malaria cases } 456(41.8 \%)-P \text {. } \\
\text { vivax }\end{array}$ & $40(8.8 \%)$ & $\begin{array}{l}\text { Jaundice- } 57.5 \% \\
\text { RF-32.5\% } \\
\text { Cerebral malaria-12.5\% } \\
\text { Thrombocytopenia-12.5\% } \\
\text { ARDS-10\% } \\
\text { Shock-7.5\% } \\
\text { Hypoglycaemia-2.5\% }\end{array}$ \\
\hline Yadav et al. [11] & 2011 & Delhi & $\begin{array}{l}147 \text { malaria cases } 89 \text { (60.5\%)- } P \text {. } \\
\text { vivax }\end{array}$ & $56(62.9 \%)$ & $\begin{array}{l}\text { Abnormal bleeding- 30.3\% } \\
\text { Impaired consciousness-20.2\% } \\
\text { Severe anaemia-17.4\% } \\
\text { Jaundice-13.5\% } \\
\text { Multiple convulsions-10.1\% } \\
\text { RF-6.1\% } \\
\text { ARDS-2.2\% } \\
\text { Metabolic acidosis and Hypo- } \\
\quad \text { glycaemia-1.1\% } \\
\text { Thrombocytopenia-81.2\% }\end{array}$ \\
\hline Singh et al. [12] & 2012-2013 & Uttar Pradesh & $\begin{array}{l}401 \text { malaria cases } 185 \text { (46.1\%)-P. } \\
\text { vivax }\end{array}$ & - & $\begin{array}{l}\text { Icterus-32.9\% } \\
\text { Severe anaemia-20.5\% } \\
\text { Cerebral malaria-15.1\% } \\
\text { Hypoglycaemia-2.1\% } \\
\text { Thrombocytopenia-51.3\% }\end{array}$ \\
\hline Chery et al. [26] & $2012-2015$ & Goa & $\begin{array}{l}1088 \text { malaria cases } 838 \text { (77\%)- } P \text {. } \\
\text { vivax }\end{array}$ & $56(78.9 \%)$ & $\begin{array}{l}\text { ARDS- } 42.9 \% \\
\text { Jaundice- } 41.1 \% \\
\text { RF-19.7\% } \\
\text { Shock-7.1\% } \\
\text { Pulmonary oedema- } 6.9 \% \\
\text { Severe anaemia- } 2.8 \% \\
\text { Abnormal bleed- } 1.4 \%\end{array}$ \\
\hline Gehlawat et al. [27] & 2013 & Haryana & $\begin{array}{l}47 \text { children with malaria } \\
35 \text { severe malaria cases enrolled }\end{array}$ & $18 / 35(51.4 \%)$ & $\begin{array}{l}\text { Impaired consciousness-50.9\% } \\
\text { Convulsions- } 44.4 \% \\
\text { Jaundice- } 27.8 \% \\
\text { Severe anaemia-27.8\% } \\
\text { Shock-16.7\% }\end{array}$ \\
\hline Kumari et al. [28] & 2014 & Maharashtra & 50 children with P. vivax malaria & $13(26 \%)$ & $\begin{array}{l}\text { Abnormal bleed- } 36.5 \% \\
\text { Impaired consciousness- 30.8\% } \\
\text { Severe anaemia- 23\% } \\
\text { ARDS-15.4\% } \\
\text { Shock-15.4\% } \\
\text { Multiple convulsions-7.7\% } \\
\text { Thrombocytopenia-94\% }\end{array}$ \\
\hline
\end{tabular}


Table 5 (continued)

\begin{tabular}{|c|c|c|c|c|c|}
\hline Study & Year of data collection & Region & No. of $P$. vivax malaria cases & $\begin{array}{l}\text { Prevalence } \\
\text { of severe vivax } \\
\text { malaria }\end{array}$ & Complications observed \\
\hline \multirow[t]{8}{*}{ Meena et al. [29] } & \multirow[t]{8}{*}{2017} & \multirow[t]{8}{*}{ Rajasthan } & \multirow{8}{*}{$\begin{array}{l}55 \text { children with malaria } 32 \\
\quad(58.2 \%)-P . \text { vivax }\end{array}$} & \multirow[t]{8}{*}{$26(60.4 \%)$} & Prostatration-49\% \\
\hline & & & & & Abnormal bleed-30.9\% \\
\hline & & & & & Severe anaemia27.3\% \\
\hline & & & & & RF-20\% \\
\hline & & & & & Shock-16.7\% \\
\hline & & & & & Convulsions-12.7\% \\
\hline & & & & & Pulmonary oedema- $2.7 \%$ \\
\hline & & & & & Thrombocytopenia-70.9\% \\
\hline \multirow[t]{8}{*}{ Mathews et al. [30] } & \multirow[t]{8}{*}{2019} & \multirow[t]{8}{*}{ Delhi } & \multirow[t]{8}{*}{150 cases of $P$. vivax malaria } & \multirow[t]{8}{*}{$63(42 \%)$} & Jaundice-36\% \\
\hline & & & & & ARDS-12.7\% \\
\hline & & & & & Abnormal bleed-8.67\% \\
\hline & & & & & Metabolic acidosis- 5.33\% \\
\hline & & & & & RF- $3.33 \%$ \\
\hline & & & & & Severe anaemia- $2.67 \%$ \\
\hline & & & & & Convulsions- $0.7 \%$ \\
\hline & & & & & Thrombocytopenia-86.64\% \\
\hline \multirow[t]{6}{*}{ Anvikar et al. [31] } & \multirow[t]{6}{*}{ 2016-2017 } & \multirow[t]{6}{*}{ Gujarat } & \multirow{6}{*}{$\begin{array}{l}50 \text { patients with Plasmodium } \\
\text { infection }\end{array}$} & \multirow[t]{6}{*}{$30(73.2 \%)$} & Prostration-90\% \\
\hline & & & & & Multiple convulsions-70\% \\
\hline & & & & & Jaundice-33.3\% \\
\hline & & & & & Severe anaemia-3.3\% \\
\hline & & & & & Abnormal bleeding-3.3\% \\
\hline & & & & & Shock-3.3\% \\
\hline
\end{tabular}

RF- Renal failure, ARDS- acute respiratory distress syndrome

Thrombocytopenia $(65.5 \%, 116 / 177)$ was reported in substantial number of patients. Jaundice $(15 \%, 30 / 177)$ and abnormal bleeding (15\%, 30/177) were the second most common severe manifestations. Multiple convulsions were also observed in $4.5 \%$ of cases. Other studies from different countries worldwide have also reported similar manifestations among severe vivax malaria cases [11]. However, renal dysfunction and ARDS were not observed in the present study, but has been observed in previous studies from India and outside India (Table 5).

Anaemia was observed in all three categories of mild, moderate and high parasitemia patients, but a significant relationship between haematological changes and parasitemia levels could not be established, unlike previous studies [26]. This could be attributed to low transmission of malaria in our region, presence of co-morbidities or a poor nutritional status of the patients. Similarly, both leukopenia and leucocytosis were observed in all categories of parasitemia. It has earlier been observed that alterations in haematological parameters in the course of a falciparum malaria infection, such as anaemia, vary with the level of malarial endemicity, background haemoglobinopathy, nutritional status, demographic factors, and malaria immunity [43]. This pattern is similar to the one observed in vivax-induced anaemia [37].

Considering the re-emergence of $P$. vivax malaria in several areas, our observations provide an insight into increased number of clinical issues related to the severity of $P$. vivax malaria (Table 5). Biological mechanism underlying the pathogenesis in $P$. vivax infections is poorly understood, in addition; there is paucity of sufficient data on this aspect. A further large-scale study is required to determine the underlying pathogenesis of the severity of the disease, and the degree to which it is related to the emerging multidrug resistance in $P$. vivax malaria. Thus, there is an urgent need to re-examine the clinical spectrum and burden of $P$. vivax malaria in our settings, so that adequate control measures can be implemented against this disease. Despite effective reduction in the transmission, there is an increase in the number of complicated $P$. vivax cases which significantly contributes to the severity and morbidity in malaria and every effort 
should be made to reduce or eliminate the malaria burden. We should also target towards reducing infections due to $P$. vivax along with $P$. falciparum in regions where both these species coexist.

\section{Limitations}

This study has few limitations. First, we were unable to make comparison of severity signs between $P$. falciparum and $P$. vivax due to low sample size of $P$. falciparum cases in the present study. Second, comorbidities such as malnutrition eliciting haematological disorders along with the aetiology of anaemia cases were not investigated. Finally, study findings drawn from low sample size of vivax patients attending this heath facility cannot reflect the whole malaria situation in the Delhi State.

\section{Conclusions}

It is notable that $P$. vivax is emerging as an important cause of malaria and morbidity in several endemic and non-endemic regions in India. In addition, the present study demonstrates the important role of $P$. vivax in complications observed in malaria disease pathogenesis. Considering the observed trend in the disease severity from the reported study there is need to strengthen the control programs targeted towards disease severity due to $P$. vivax.

\begin{abstract}
Abbreviations
ALT: Alanine aminotransferase; ARDS: Acute respiratory distress syndrome; AS: Artesunate; AST: Aspartate aminotransferase; Cl: Confidence interval; CNS: Central nervous system; df: Degree of freedom; Hb: Haemoglobin; MCH: Mean corpuscular haemoglobin; MCV: Mean corpuscular volume; PBS: Peripheral blood smears; PQ: Primaquine; RBC: Red blood cells; RF: Renal failure; RMAT: Rapid malaria antigen test; SBP: Systolic blood pressure; SD: Standard deviation; SP: Sulfadoxine-Pyrimethamine; TLC: Total leucocytes count; WBC: White blood cells; WHO: World health organisation.
\end{abstract}

\section{Acknowledgments}

The authors are grateful to all patients that agreed to take part in the present study. The authors would also like to thank Ms. Shikha Puri of VMMC \& Safdarjung Hospital, for her technical assistance without whom the study would not have been possible.

\section{Authors' contributions}

MM and VS designed the study. MM, NM and VD participated in the data collection and laboratory analysis. MM, LPK and VS analysed and interpreted the data and wrote the manuscript. LPK performed statistical analysis with the help of MM and VS. MM wrote the first version of the manuscript. LPK and VS revised the manuscript for intellectual content. MM and VS supervised the work at all stages. All authors read and approved the final manuscript.

\section{Funding}

No funding source to report.

\section{Availability of data and materials}

All datasets on which the conclusions of the research rely are presented in this paper. However, data is available from the corresponding author on reasonable request.

\section{Ethics approval and consent to participate}

Ethical clearance was taken by the Ethics Committee before the commencement of the study [IEC/SJH/VMMC/Project/2017/983]. A written informed consent was obtained from each study participant or guardian of the wards and confidentiality of the participant's test results was ensured throughout the research.

\section{Consent for publication}

All authors agree for publication of the present paper.

\section{Competing interests}

The authors declare that they have no competing interests.

\section{Author details}

1 Department of Microbiology, Vardhman Mahavir Medical College and Safdarjung Hospital, New Delhi, India. ${ }^{2}$ Cell Biology Laboratory and Malaria Parasite Bank, ICMR-National Institute of Malaria Research, New Delhi, India.

Received: 21 July 2020 Accepted: 20 October 2020

Published online: 30 October 2020

\section{References}

1. WHO. World malaria report 2019. 2019; 1-282. www.who.int.

2. WHO. World Malaria Report 2014. 2014; pp. 1-242. www.who.int.

3. Cowman, et al. Malaria: biology and disease. Cell. 2016;167:610-24. https ://doi.org/10.1016/j.cell.2016.07.055.

4. Ashley EA, Pyae Phyo A, Woodrow C. Malaria. Lancet. 2018;391:1608-21. https://doi.org/10.1016/S0140-6736(18]30324-6.

5. Anstey NM, Douglas MN, Poespoprodjo JR, Price RN. Plasmodium vivax: Clinical spectrum, risk factors and pathogenesis. Adv Parasitol. 2012;80:151-201. https://doi.org/10.1016/B978-0-12-397900-1.00003-7.

6. Wyss K, Wangdahl A, Vesterlund M, Hammar U, Dashti S, Naucher P, et al. Obesity and diabetes as risk factors for severe Plasmodium falciparum malaria: results from a Swedish Nationwide study. Clin Infect Dis. 2017;65:949-58. https://doi.org/10.1093/cid/cix437.

7. Dini S, Douglas NM, Poespoprodjo JR, Kenangalem E, Sugiarto P, Plumb $I D$, et al. The risk of morbidity and mortality following recurrent malaria in Papua, Indonesia: a retrospective cohort study. BMC Med. 2020;18:28. https://doi.org/10.1186/s12916-020-1497-0.

8. Rahimi BA, Thakkinstian A, White NJ, Sirivichavakul C, Dondorp AM, Chokejindachai W. Severe vivax malaria: a systematic review and metaanalysis of clinical studies since 1900. Malar J. 2014;13:481. https://doi. org/10.1186/1475-2875-13-481.

9. Anivkar AR, Shah N, Dhariwal AC, Singh Sonal G, Mohan Pradhan M, Ghosh SK, et al. Epidemiology of Plasmodium vivax malaria in India. Am J Trop Med Hyg. 2016;95:108-20. https://doi.org/10.4269/ajtmh.16-0163.

10. Ghosh SK, Rahi M. Malaria elimination in India - the way forward. J Vector Borne Dis 2019;56:32-40. https://www.jvbd.org/text. asp?2019/56/1/32/257771

11. Yadav G, Pardeshi G, Roy N. Clinico-epidemiological profile of patients admitted with Plasmodium vivax malaria in a tertiary care hospital, Delhi. Int J Comm Med Public Health. 2018;12:5420-4.

12. Singh N, Mathur A, Naim F, Agarwal N. The changing clinical spectrum of malaria: a clinical study from Bundelkhand. IOSR J Dental Med Sci. 2014;13:37-40.

13. National Vector Borne Disease Control Program. Epidemiological situation Report in India. https://nvbdcp.gov.in/Doc/Annual-Report-2017.pdf

14. National Vector Borne Disease Control Program. Endemicity of malaria from 2016 to 2018. www.nvbdcp.gov.in

15. Moody A. Rapid diagnostic tests for malaria parasites. Clin Microbiol Rev. 2002;15:66-78. https://doi.org/10.1128/cmr.15.1.66-78.2002.

16. Trape J-F. Rapid evaluation of malaria parasite density and standardization of thick smear examination for epidemiological investigations. Trans R Soc Trop Med Hyg. 1985;79:181-4. https://doi.org/10.1016/00359203(85)90329-3.

17. WHO. Guidelines for the treatment of malaria-third edition. https:// www.ncbi.nlm.nih.gov/books/NBK294440/pdf/Bookshelf_NBK294440.pdf (2015). 
18. NIMR and NVBDCP. Guidelines on diagnosis and treatment of malaria in India, 2014. 2014, Third edition, vol 113: 20 pages. https://www.slideshare .net/Dr_Padmesh/malaria-guidelines-2014

19. White NJ. Malaria Lancet. 2014;391:1608-21. https://doi.org/10.1016/ S0140-6736(18]30324-6.

20. Rénia L, Howland SW, Claser C, Gruner AC, Suwanarusk R, Teo TH, et al. Cerebral malaria: mysteries at the blood-brain barrier. Virulence. 2012;3:193-201. https://doi.org/10.4161/viru.19013.

21. Carvalho BO, Lopes SCP, Nogueira PA, Orlandi PP, Bargieri DY, Blanco YC, Mamoni R, et al. On the cytoadhesion of Plasmodium vivax-infected erythrocytes. J Infect Dis. 2010;202:638-47.

22. Totino PR, Lopes SC. Insights into the cytoadherence phenomenon of Plasmodium vivax: The putative role of phosphatidylserine. Front Immunol. 2017;8:1148. https://doi.org/10.3389/fimmu.2017.01148.

23. Akinosoglou KS, Solomou EE, Gogos CA. Malaria: a haematological disease. Hematol. 2012;17:106-14. https://doi.org/10.1179/102453312X 13221316477336

24. López C, Yepes-Pérez Y, Hincapié-Escobar N, Díaz-Arévalo D, Patarroyo MA. What is known about the immune response induced by Plasmodium vivax malaria vaccine candidates? Front Immunol. 2017;8:126. https://doi. org/10.3389/fimmu.2017.00126.

25. Kochar DK, Das A, Kochar SK, Saxsena V, Sirohi P, Garg S, et al. Severe Plasmodium vivax malaria: a report on serial cases from Bikaner in Northwestern India. Am J Trop Med Hyg. 2009;80:194-8. https://doi.org/10.4269/ ajtmh.2009.80.194.

26. Chery L, Maki JN, Mascarenhas A, Walke JT, Gawas P, Almeida A, et al. Demographic and clinical profiles of Plasmodium falciparum and Plasmodium vivax patients at a tertiary care centre in southwestern India. Malar J. 2016;15:569. https://doi.org/10.1186/s12936-016-1619-5.

27. Gehlawat VK, Arya V, Kaushik JS, Gathwala G. Clinical spectrum and treatment outcome of severe malaria caused by Plasmodium vivax in 18 children from northern India. Pathog Glob Health. 2013;107:210-4. https ://doi.org/10.1179/2047773213Y.0000000096.

28. Kumari M, Ghildiyal R. Clinical profile of Plasmodium vivax malaria in children and study of severity parameters in relation to mortality: a tertiary care centre perspective in Mumbai. India Malar Res Treat. 2014;2014:1-6.

29. Meena HM, Sharma BS, Gupta ML, Sharma A, Choudhary R, Sharma P. Clinico-laboratorical spectrum of malaria in children: emerging new trends. Curr Pediatr Res. 2017;21:384-8.

30. Mathews SE, Bhagwati MM, Agnihotri V. Clinical spectrum of Plasmodium vivax infection, from benign to severe malaria: a tertiary care prospective study in adults from Delhi, India. Trop Parasitol. 2019;9:88-92. https://doi. org/10.4103/tp.TP_2_19.

31. Anvikar AR, van Eijk AM, Shah A, Upadhyay KJ, Sullivan SA, Patel AJ, et al. Clinical and epidemiologicalcharacterization of severe Plasmodium vivaxmalaria in Gujarat, India. Virulence. 2020;11:730-8. https://doi. org/10.1080/21505594.2020.1773107.
32. Gai PP, Mockenhaupt FP, Siegert K, Wedam J, Boloor A, Kulkarni SS, et al. Manifestation of malaria in Mangaluru, southern India. MalarJ. 2018;17:313. https://doi.org/10.1186/s12936-018-2462-7.

33. Im JH, Yoon Kwon H, Wook Park S, Durey A, Hee Lee K, Chung M-H, et al. Severe Plasmodium vivax infection in Korea. Malar J. 2017;16:51. https:// doi.org/10.1186/s12936-017-1684-4.

34. Geleta G, Ketema T. Severe malaria associated with Plasmodium falciparum and P. vivax among children in Pawe hospital. Northwest Ethiopia Malar Res Treat. 2016. https://doi.org/10.1155/2016/1240962.

35. Ketema T, Bacha K. Plasmodium vivax associated severe malaria complications among children in some malaria endemic areas of Ethiopia. BMC Public Health. 2013;13:637. https://doi.org/10.1186/1471-2458-13-637.

36. Douglas NM, Lampah DA, Kenangalem E, Simpson JA, Poespoprodjo JR, Sugiarto $P$, et al. Major burden of severe anemia from non-falciparum malaria species in Southern Papua: a hospital-based surveillance study. PLoS Med. 2013;10:e1001575. https://doi.org/10.1371/journ al.pmed.1001575.

37. Douglas NM, Anstey NM, Buffet PA, Poespoprodjo JR, Yeo TW, White NJ, et al. The anaemia of Plasmodium vivax malaria. Malar J. 2012;11:135. https ://doi.org/10.1186/1475-2875-11-135.

38. Umbers AJ, Aitken EH, Rogerson SJ. Malaria in pregnancy: small babies, big problem. Trends Parasitol. 2011;27:168-75. https://doi.org/10.1016/j. pt.2011.01.007.

39. Rijken MJ, Papageorghiou AT, Thiptharakun S, Kiricharoen S, Dwell SLM, Wiladphaingern J, et al. Ultrasound evidence of early fetal growth restriction after maternal malaria infection. PLOS ONE. 2012;7:e31411. https:// doi.org/10.1371/journal.pone.0031411.

40. Datta M, Biswas J, Dasgupta S, Banerjee K, Choudhury S, Sengupta SK, et al. Comparative study on antenatal and perinatal outcome of vivax and falciparum malaria in a tertiary care hospital of Kolkata India. J Clin Diag Res. 2017;11:QC01-4. https://doi.org/10.7860/JCDR/2017/23051.9195.

41. Hirani M, Vadhvana SK. Study of clinical profile of P. vivax malaria in pregnancy. J Res Med Dental Sci. 2015;3:3076311. https://doi.org/10.5455/ jrmds.20153414.

42. Bardají A, Martinez-Espinosa FE, Arévalo-Herrera M, Padilla N, Kochar S, Ome-Kaius $M$, et al. Burden and impact of Plasmodium vivax in pregnancy: a multi-centre prospective observational study. PLoS Negl Trop Dis. 2017;11:e0005606. https://doi.org/10.1371/journal.pntd.0005606.

43. Price RN, Simpson JA, Nosten F, Luxemburger C, Hkirjaroen L, Ter Kuile $F$, et al. Factors contribution to anemia after uncomplicated falciparum malaria. Am J Trop Med Hyg. 2001;65:614-22. https://doi.org/10.4269/ ajtmh.2001.65.614.

\section{Publisher's Note}

Springer Nature remains neutral with regard to jurisdictional claims in published maps and institutional affiliations.
Ready to submit your research? Choose BMC and benefit from:

- fast, convenient online submission

- thorough peer review by experienced researchers in your field

- rapid publication on acceptance

- support for research data, including large and complex data types

- gold Open Access which fosters wider collaboration and increased citations

- maximum visibility for your research: over $100 \mathrm{M}$ website views per year

At BMC, research is always in progress.

Learn more biomedcentral.com/submissions 